\title{
Evaluation and human rights educational policies: contradictions between regulation and emancipation in basic education in Brazil
}

\author{
Ana Maria Eyng a \\ Thais Pacievtch a \\ Maria de Lourdes do Prado K. D'Almeida ${ }^{a}$ \\ Maria Lourdes Gisi ${ }^{b}$
}

\begin{abstract}
This study aims to analyze the contradictions between anthropological and teleological aspects of evaluation and human rights in educational policies for basic education in Brazil. The study focuses on the contradictions by analyzing policy documents related to the two themes. The results suggest the ways that contradictions in the anthropological and teleological perspectives assumed by these policies obstruct provision of basic education that includes social quality. Basic educational evaluation policies are aimed at regulation, seeking to produce indices that normalize and homogenize the subjects of education, legitimizing identities. On the other hand, human rights educational policies aim to emancipate subjects by considering the diversity that characterizes and organizes them, enabling the creation of resistance and project identities that can operate from a counter-hegemonic perspective.
\end{abstract}

Keywords: Public policies. Evaluation. Human rights.

Pontifícia Universidade Católica do Paraná, Programa de Pós-graduação em Educação - PUCPR/PPGE, Grupo de Pesquisa Políticas Públicas e Formação de Professores. Curitiba, Paraná, Brasil.

b Pontifícia Universidade Católica do Paraná, Programa de Pós-graduação em Educação - PUCPR/PPGE, Grupo de Pesquisa Fundamentos Epistemológicos das Políticas Educacionais e a Problemática na Escola na Contemporaneidade. Curitiba, Paraná, Brasil. 


\section{Introduction}

The anthropological focus on humans and the teleological focus on objectives in educational policies that consider large-scale evaluations ${ }^{1}$ and human rights education $^{2}$ in basic education ${ }^{3}$ are the analytical dimensions of these policies. The assumptions, which attest the analysis, are based on two main findings. The first one refers to the basic evaluation of educational policies aimed at regulations that emphasize establishing indices that standardize test results. The second one refers to human rights educational policies that seek to emancipate subjects. The contradictions between these perspectives are evident in the articulation of these assumptions. Therefore, the question we address is: what effects do these contradictions have on the objectives and subjects (students and teachers) of basic education?

Thus, our purpose in this text seeks to make explicit the effects of assessment on a large scale and human rights education in subjectivities, through effectuation of the purposes of education having as a central category the contradiction between regulation and emancipation.

The analysis of the theme refers to the context of international influence in which they are produced and from which emanates guidelines that reflect on national documents relating to educational policies. In this context, there is an intense process of transfer and mobility of policies, as pointed out in the studies that Stephen Ball has been developing since the 1980s, noting the influences and effects on educational reforms arising from state reforms. "The term policy transfer refers to an amalgam of diverse ideas that attempt to capture and model the ways in which policy knowledge circulates globally." Therefore, the concept of transfer is related to policies developed elsewhere and that would be 'imported' for policy enforcement by multilateral agencies; and structural convergence processes" (BALL, 2014, p. 36, the author highlights). Policies move themselves

[...] by networks of social relations or of negotiations and be adapted by them, involving participants with a variety of interests, commitments purposes and influences, which are joined by

\footnotetext{
1 The National Basic Education Evaluation System, which has existed in Brazil since 2005.

2 The Human Rights Education provided for in PNEDH 2006 and, particularly, in Resolution No. 1/2012-Establishes National Guidelines for Human Rights Education.

3 Comprises early childhood education (daycare for ages 0-3 and preschool for ages 4 and 5), primary school (ages 6 to 14) and secondary school (ages 15 to 17 ).
} 
subscribing to a discursive set circulating within this network of relationships and it is legitimized by it (BALL, 2014, p. 36) .

In this process of circulation, Ball $(2014$, p.37) analyzes what he considers the main axes of global trends in education policy that would be the "choice of schools by parents and the role of private schooling", therefore the privatization of education. Another axis would be the "reform of public education systems along the line managerial / entrepreneurial" changing management practices.

Thus, we observe the mobility of global political processes in which hybrid policies are produced, resulting from recontextualizations in local contexts. The tensions and contradictions in the field of educational policies are present in very clear way in the global context, focusing crucially on local policies.

The regulation as state strategy in the management of educational policies linked to market has roots in the scenario constructed from the economic crisis in Britain and the United States in the 1980s, producing a new "paradigm of educational administration" which disseminates "market strategies as master narrative "(BALL, 2001, 2010, 2013, 2014). The design and consequent activities of welfare state, the providing state becomes minimal state, the regulatory state. The guidelines, which establish economic indicators for educational policies, are disseminated and strongly influenced by multilateral agencies such as the World Bank, OECD and $\mathrm{WMO}$, by providing consulting services.

On the other hand, emancipation as strategy of civil society with roots in the decolonization process, was included in the studies on the question of identity in post-colonialism. We highlight Boaventura de Souza Santos' studies, who criticizes the dichotomy state / civil society, proposing the need for a counter-hegemonic globalization that promotes social emancipation as a result of the struggles of the social movements of resistance, minorities who complain and claim the overcoming of inequalities and exclusion resulting from hegemonic neoliberal globalization (SANTOS, 1989, 1997, 2008, 2009, 2010, SANTOS; MENEZES, 2013).

Thus, the right to inclusion, to difference which lead to emancipation, now have resonance in epistemological discussions and social policies. The guidelines, which establish emancipatory social indicators for educational policies, are disseminated by international organizations, among which we highlight UNESCO.

4 Note: The translation of the text into English, including textual citations, was made by Gisele Rietow Bertotti - Undergraduated in Languages - Portuguese and English, Post-graduate degree in Foreign Language Teaching, Master in Education and taking the PhD in Education. 
The contextualization of the discussion on the contradiction regulation-emancipation, has as its main reference the contributions of Ball and Santos, internationally recognized authors. In the analysis we emphasize the production of Brazilian José Dias Sobrinho $(2002,2008,2015)$ and the production of the Portuguese Almerindo Janela Afonso (2007, 2009a,b). This is therefore an issue that has relevance in transnational discussions, which emerge in the 1980s, and it has been enlarged and deepened in subsequent decades, maintaining its relevance and vitality to this day.

In dialogue with these references are discussed documents of Brazilian educational policies, CF 1988 (BRASIL, 1988), Law no. 9394/96 (BRASIL, 1996), National Plan for Human Rights Education (BRASIL, 2007a), Decree No. 6.094/2007 (BRASIL, 2007b), Law no. 13.005/2014 (BRASIL, 2014). And, in particular Resolution no. 04/2010 (BRASIL, 2010) and Resolution no. 01/2012 (BRASIL, 2012). A document analysis according to Cellard (2010, p. 299-302) requires initially to observe five dimensions that facilitate its interpretation and that refers to "global social context in which it was produced"; "author or authors" the "authenticity and reliability of the text"; the "nature of the text" and the "key concepts and the internal logic of the text." After this identification starts the analysis process itself in which it is necessary to "discover the links between the accumulated facts, between the elements of information" and is

[...] this concatenation of connections between the problems of the researcher and the various observations taken its documentation, which allows it to formulate plausible explanations, produce a coherent interpretation, and perform a reconstruction of a particular aspect of a given society, at this or that moment (CELLARD, 2010, p. 304).

The scrutiny of the documents was possible from the content analysis of official documents that regulate the educational policies in Brazil. Content analysis consists in a set of analytical techniques that aim, through systematic procedures and description of the contents of message, obtain " [...] indicators (quantitative or not) that allow the inference of knowledge related to conditions of production / reception (inferred variables) of these messages" (BARDIN, 1995, p. 38). Such analysis is carried out in three stages: 1) pre-analysis, 2) exploration of material and 3) treatment of objective results and interpretation. When the results are significant, the analyst "[...] can then propose inferences and interpretations and advance the purpose of the planned objectives, or which relate to other unexpected discoveries" (BARDIN, 1995, p. 101). 


\section{Anthropological and teleological characteristics of Brazilian educational policies}

The concepts surrounding education that define the selection and defense of educational principles and proposals reflect a certain worldview. These conceptual and empirical options are a major challenge because they are configured in numerous historical, social, economic, political, and cultural contexts, in which the objectives of policy formation and the identitarian profiles of the subjects of education are numerous and marked by power relations.

In this interplay of forces, individual and collective identities are impregnated with characteristics and values by their contexts, forged by dominant institutions, and internalized by the social actors (CASTELLS, 2008, p. 23). Considering that the social construction of identity always occurs in contexts marked by power relations, Castells (2008, p. 24) proposes a distinction among three types and origins of identity construction. The first is a Legitimizing Identity, in which the dominant institutions use mechanisms to extend and rationalize their domination. The second is a Resistance Identity, in which excluded individuals and groups use resistance and survival mechanisms. The third is a Project Identity, which involves mechanisms that seek to transform the entire social structure.

In the process of subject formation, the intentionalities articulated in educational objectives indicate the characteristics that they intend to establish. These characteristics indicate translations, which convey assumptions of modernity that operate with the contradictions existing between regulation and emancipation. "The paradigm of modernity comprises two main forms of knowledge: knowledge-emancipation and knowledge-regulation" (SANTOS, 2009, p. 78). The linking and articulation in dynamic equilibrium between these two models of knowledge assumptions in modern thought, under the aegis of three logics of rationality: "rationality live-practice, the expressive aesthetic rationality and cognitive-instrumental rationality." However, "[...] in the last two years, cognitive-instrumental rationality of science and technology has been imposing on others." (SANTOS, 2009, p. 79). Thus, the superiority of regulation over emancipation deregulated the necessary balance within the dynamic of regulation and emancipation.

Therefore, contradictions, the genesis of which arises from modernity, linger in the propositions of educational policies, in a context characterized as postmodern. They are perceptible formative trajectories grounded in knowledge-regulation, as Santos (2009, p. 78) explains, "Knowledge-regulation is a trajectory from a state of ignorance that I call chaos to a state of knowing that I call order." 
This order, or ordering, which can also be termed "standardizing," is the focus of evaluation policies. On the other hand, human rights educational policies claim that, "Knowledge-emancipation is a trajectory from a state of ignorance that I call colonialism to a state of knowing that I call solidarity" (SANTOS, 2009, p. 78).

An unequal focus on regulation and emancipation that causes tensions between the possibilities of identity construction exists in the anthropological and teleological concepts in educational policies. The intentionalities are antagonistic regarding the actions proposed and the results constructed. If regulation "progresses from chaos to order, "emancipation" progresses from colonialism to solidarity" (SANTOS, 2009, p. 78).

Regulation has been the cornerstone of the evaluation mechanism that recently has become central to educational policies. Evaluative concepts and processes focus on educational objectives and the identitarian configuration of the subjects of and/or in education. As Dias Sobrinho (2005) notes, "all evaluation is connected to a set of values and interests that has to do with the destinations of individuals and societies" (p. 16). Therefore, evaluation has a social and inter-subjective nature, "that questions and produces meanings, perceptions and knowledge, which constitute the subjects' positions before a reality" (DIAS SOBRINHO, 2008 , p. 200). From this perspective, the author warns that evaluation "cannot be restricted to mere application and cold analyses of results from instruments seen as objective and neutral, which could engender definitive and unquestionable judgments" (DIAS SOBRINHO, 2008, p. 200).

"Education is a social and relational phenomenon, a human practice of social subjects" (DIAS SOBRINHO, 2008, p. 200). Hence, it is important to understand the contexts and life circumstances of children, adolescents, and young adults as subjects with rights, considering that school is a space intended to protect human rights. The right to an education is guaranteed through "access to the teaching, permanence, equality and quality of education," which is enabled in emancipatory processes via liberating actions that can provoke criticism and, as Saul (1999, p. 61) describes, liberate the subjects from deterministic conditionings (i.e., enabling knowledge-emancipation).

Thus, differentiated pedagogical processes capable of provoking dialogue are required, in which the equality and/or varied circumstances among the students and the contexts in which learning occurs are considered. Along these lines, "all the different ways of being and learning are valorized and subsidize didactic alternatives" (HOFFMANN, 2001, p. 154). Therefore, evaluation will be 
established as a process intended to constitute and emancipate subjects, developing "a participatory practice and an ethical enterprise in the service of strengthening the social responsibility of education" (DIAS SOBRINHO, 2008, p. 194).

This perspective demonstrates the assumptions of an anthropological viewpoint that is embodied in the emancipatory objectives of school education that is "understood primarily as the scientific and socially relevant fulfillment of knowledge production and subject formation processes with epistemological, moral, social and political autonomy" (DIAS SOBRINHO, 2008, p. 194). Similarly, Afonso (2007, p. 20) states, "I thus contend that a quality (public or private) school can only be a school that is both democratic and has high possibilities for providing effective learning in scientific, technical and humanistic terms."

However, current evaluation policies have not been developed in this direction. Although based on a commitment to providing universal quality education, they emphasize indices for identifying established quantitative goals. In this context, performances "of individual subjects or organizations - serve as measures of productivity or results, as forms of presenting quality or moments of promotion or inspection" (BALL, 2010, p. 38, emphasis in the original).

At issue is the right to a quality education beyond the quantitative aspects that can be parameterized by the indices. "Quality should not only be scientific, but also pedagogical and democratic - and the evaluation of these qualities cannot be restricted to the application of standardized tests or other similar forms of external evaluation" (AFONSO, 2007, p. 20). However, in the popular evaluation models, school practices mostly focus on students' grades and on averages, and not on factors that likely are more important to civic life.

The emphasis given to evaluation of basic education in educational policies, the mechanisms used in its processes, and the actions taken by schools regarding evaluations are markedly positivist. The results are seen in greater selectivity, discrimination, and exclusion, through the "promotion of school rankings and other equally debatable mechanisms inducing educational quasi-markets or enablers of spurious forms of competition and emulation among the main school actors" (AFONSO, 2007, p. 17). Moreover, the author concludes that, "all this, under the justification of the necessary increase in the state's economic competitiveness, efficiency and effectiveness and improving the quality of school education" (AFONSO, 2007, p. 18). These effects are obvious and they do not contribute to the goal of improving educational quality, in that they are "first representing an unjustifiable political and educational retrogression when compared to the 
scientific and epistemological advances that have been leading evaluation to anti-positivist, more complex, pluralistic, democratic and objective perspectives" (AFONSO, 2007, p. 20).

The pressure that results from the ranking system of large-scale evaluations leads to the revision of curricula based on the contents of the evaluations and, currently, causes the demand for a more specific determination of "what" and "when" to teach, disregarding the contexts and subjects that actually give life to the curricula and schools. The resultant unified curriculum has hegemonic characteristics that can legitimize the exclusion of diversity.

The tension and contradiction between evaluation policies that emphasize regulation and human rights educational policies aimed at emancipation are therefore evident. As Torres Santomé (2013, p. 216) explains, "the current diversity of students does not fit well within school institutions designed to standardize and impose a cultural canon that few people normally question." The students lack of interest in school, as well as the evasion, lack of discipline, and violence in schools are symptoms of this tension, which, combined with the "political, social, cultural, economic and professional revolutions taking place at a dizzying pace" (TORRES SANTOMÉ, 2013, p. 226), have been disconcerting to educational professionals.

We should be aware that there are many students in the current education system who do not feel recognized, among other reasons because the social, cultural, linguistic and ethnic groups to which they belong do not exist in the cultural content studied in schools, let alone the didactic materials they use for their schoolwork (TORRES SANTOMÉ, 2013, p. 226).

Thus, in addition to disregarding subjects and processes in favor of measurable indicators and results, current evaluation processes and the rankings that rely on them began to forge the current curricula of educational institutions and promote the establishment of a unified national curriculum, which reinforces the standardization of the curricula and evaluations.

\section{Evaluation and quality of basic education via regulation}

The purpose of education in democracy, according to Adorno (1995) objectifies. "[...] the production of a real awareness. This would be even of greater political importance, its idea, if it is allowed to say so, is a political demand". Since "[...] a democracy with the duty to not only work, but operate as its concept, demands 
emancipated people. A democracy can only be imagined while a society of who is emancipated (ADORNO, 1995, p.14-142). Adorno understands that it is necessary to take into account the "immeasurable weight of obfuscation of the existing awareness" and that education cannot fail to prepare men for guidance in the world, but also cannot just worry about having well-adjusted people so the task would be to "strengthen the resistance to strengthen adaptation" (ADORNO, 1995, p. 143-144)

With the promulgation of the Constitution in 1988, which has taken over the principles of democratic constitutional state constituted from the political opening, education is regarded, in Article 6 of the Constitution, as the first of social rights, and further described in Article 205, as a right of all and duty of the state and the family (BRASIL,1988). The responsibility of the State in relation to education is also emphasized in Article 208, in which it is determined that "access to compulsory and free education is a subjective public right" $(\S 1)$, being established that "not provide compulsory education by public power, or their irregular supply, culminates in responsibility of the competent authority " $(\S 2)$ (SAVIANI, 2013, p. 746).

However, the right to education is not limited to access to different levels of education, but "should have as scope the offer of conditions for the full development of numerous individual capacities" (DUARTE, 2004, p. 115), which go beyond those required by the labor market, since "the human being is an inexhaustible source of growth and expansion in the intellectual, physical, spiritual, moral, social and creative plane" (DUARTE, 2004, p. 115).

Based on democratic principles expressed in the 1988 Constitution, the Law of Guidelines and Bases of Education (Law 9394/96), published in 1996, it is accelerated the process of democratization of access to basic education, including among the tasks of the Union (Article 9), the task of "ensuring national evaluation process of school performance in primary, secondary and higher education, in collaboration with the education systems", with the objective of "setting priorities and improving the quality of education" (BRASIL, 1996).

Thus, the evaluation of large-scale of school performance of basic education challenge is established from the Law of Guidelines and Bases of Education, and announced since the genesis as a parameter for the improvement of teaching quality. However, the evaluation process has gradually accentuated the emphasis on regulation of the results apparently the priorities do not go much beyond the improvement of quantitative indicators for school performance, weakening priorities setting that are intended to raise awareness, which enables emancipation. 
Legislation over the years has been making regulation more explicit, it is what is observed in Decree No. 6094/2007, which establishes the All for Education Goals and Commitment Plan, regulation (evidenced by the chaos-order trajectory) is more explicitly emphasized. Article 2 of this Decree defines twenty-eight guidelines that should serve as the foundation of the actions to be developed to improve the quality of basic education (BRASIL, 2007b). What we can identify as the anthropological view underlying this legal document emerges from these guidelines. The subject (student) is understood as open to the learning and development that should be considered in their individuality and specificity, aimed at learning per se and combating evasion. The subject is a potentially ethical, artistic, and physical being; in other words, configured by values and creativity as well as by its physical aspects and biological diversity, demonstrated in the reference to including people with special educational needs. Furthermore, it is a communitarian and participatory subject and one of relations.

Although the Decree's objective is explained in Article 1 as "combining efforts from the Union, States, Federal District and Municipalities, acting in collaboration with families and the community, in favor of improving the quality of basic education," the document does not explicitly define an objective of education, or even of evaluation. The objective of education would be learning, considering the language in Article 2, item 1, which sets the first guideline, "to establish learning as the focus, indicating concrete results to be achieved." However, learning that has concrete results (measurable by evaluations) is not the only evidence of learning that can result from the educational process.

The Decree defines the ways that the Basic Education Evaluation System is to be used to measure the Basic Education Development Index (Índice de Desenvolvimento da Educação Básica - IDEB) as,

Article 3 - The quality of basic education will be measured objectively, based on the IDEB, calculated and published periodically by the INEP, using data on school performance, combined with student performance, contained in the school census and the Basic Education Evaluation System (Sistema de Avaliação da Educação Básica-SAEB), comprising the National Basic Education Evaluation (Avaliação Nacional da Educação Básica-ANEB) and the National Student Performance Evaluation (Prova Brasil) (BRASIL, 2007b).

It is possible to infer from the Decree that the implied objective of evaluation is reduced to measurement based on the notion that education can be reduced 
to what can be quantitatively observed, regardless of the fact that evaluating is broader than mere measurement. According to Fernandes and Freitas (2007, p. 19), "evaluation is a process in which conducting tests and assigning grades is only part of the whole."

Another aspect that can be noted in the Decree is that educational quality is defined as essentially those things that can be measured by periodic evaluations of student performances and school achievements. These evaluations, applied on a large scale at a national level, ignore national diversity among the subjects and contexts of and in Brazilian education and that focus on quality. In addition, unfortunately, the finding made by Hoffman more than two decades ago, in 1993, on the publication of the first edition of the work, is still up-to-date.

One must pay attention to the fact that a quality school is one that is aware of all the Brazilian children conceived in its concrete reality. And school, today, is part of a society marked by a lot of violence, poverty, epidemics, economic and political instability. The path to development is an egalitarian education that welcomes the children of this conflict and projects this generation into the future, conscious of their role in a possible transformation (HOFFMANN, 2001, p. 16).

The greater or lesser emphases of these policies (LDB No. 9394/96 and Decree No. 6094/2007) on regulation rather than emancipation evidences the attempt ${ }^{5}$ (which we can say is already successful) to insert certain concepts, such as "performativity."

Quality in basic education is measured to monitor the progress of public policies using a combined analysis of student performance on exams and pass rates of the schools (BRASIL, 2007b). The IDEB uses a scale ranging from 0 to 10 with level 6 as the reference value, which, according to Soares and Xavier (2013), corresponds to level 3 of the Programme for International Student Assessment (PISA). The launch of PISA occurred in 1997, being the first version of the program implemented in 43 countries members of the Organization for Economic Cooperation and Development (OECD) in 2000. In 2015, PISA has been applied in over 70 countries (OECD, 2016).

Results of the IDEB and the PISA are presented in Tables 1 and 2, published by the Instituto Nacional de Estudos e Pesquisas Educacionais (Brazil) (INEP).

This attempt is made by the Organisation for Co-operation and Economic Development (OECD), which spread a new paradigm based on three key elements: market type, management, and performativity (BALL, 2001, p. 105). 
Table 1. Programme for International Student Assessment (PISA) averages.

\begin{tabular}{lccccc}
\hline PISA & $\mathbf{2 0 0 0}$ & $\mathbf{2 0 0 3}$ & $\mathbf{2 0 0 6}$ & $\mathbf{2 0 0 9}$ & $\mathbf{2 0 1 2}$ \\
\hline OECD & 500 & 497 & 497 & 500 & 498 \\
BRAZIL & 368 & 383 & 384 & 401 & 402 \\
\hline
\end{tabular}

Source: BRASIL, INEP - Instituto Nacional de Estudos e Pesquisas Educacionais Anísio Teixeira (BRASIL, 2011).

Table 2. Basic Education Development Index (IDEB) by grade level.

\begin{tabular}{lccccc}
\hline IDEB & $\mathbf{2 0 0 5}$ & $\mathbf{2 0 0 7}$ & $\mathbf{2 0 0 9}$ & $\mathbf{2 0 1 1}$ & $\mathbf{2 0 1 3}$ \\
\hline Early years of primary school & 3.8 & 4.2 & 4.6 & 5.0 & 5.2 \\
Later years of primary school & 3.5 & 3.8 & 4.0 & 4.1 & 4.2 \\
Secondary school & 3.4 & 3.5 & 3.6 & 3.7 & 3.7 \\
\hline
\end{tabular}

Source: BRASIL, INEP - Instituto Nacional de Estudos e Pesquisas Educacionais Anísio Teixeira (BRASIL, 2011).

Although Brazil's scores are near the OECD average, they were consistently lower between 2000 and 2012 in all areas. However, it should be noted that student performance indicators are useful only when they are analyzed in the contexts in which they occur. As Soares and Xavier (2013, p. 915) note, "the use of an indicator as the only measure of school and system quality will naturally cause schools to seek to maximize it, and this [...] can lead to a dysfunctional educational system." In the case of the IDEB, those authors warn of an existing limitation to interpretation in that only the students present in the classroom at the time of the evaluations are assessed; and 50 percent student participation is acceptable to the INEP.

The importance attached to large-scale evaluations can be found in the new National Education Plan (Law No. 13005/2014), which includes a specific goal for evaluation and projects the IDEB and PISA 2021, as shown by the data in Tables 3 and 4 . To achieve this goal, the Plan presents 36 strategies regarding the conditions that should exist. Goal 7 is to, "enhance the quality of basic education in all stages and modalities, with improved school flow and learning in order to achieve the following national averages for the IDEB" (BRASIL, 2014).

Strategy 7.11 refers to performance on the PISA; it is designed to "improve the performance of basic education students on learning evaluations in the Programme for International Student Assessment (PISA), used as an internationally recognized external reference tool, according to the following projections (BRASIL, 2014). 
Table 3. Projections of the IDEB (2015-2021) in the National Education Plan.

\begin{tabular}{lccccc}
\hline IDEB & $\mathbf{2 0 1 5}$ & $\mathbf{2 0 1 7}$ & $\mathbf{2 0 1 9}$ & $\mathbf{2 0 2 1}$ & $\mathbf{2 0 2 1}$ \\
\hline Early years of primary school & 5.2 & 5.5 & 5.7 & 6.0 & 6.0 \\
Later years of primary school & 4.7 & 5.0 & 5.2 & 5.5 & 5.5 \\
Secondary school & 4.3 & 4.7 & 5.0 & 5.2 & 5.2 \\
\hline
\end{tabular}

Source: Brasil (2014).

Table 4. PISA Projection (2015-2021) in the National Education Plan.

\begin{tabular}{lccc}
\hline PISA & $\mathbf{2 0 1 5}$ & $\mathbf{2 0 1 8}$ & $\mathbf{2 0 2 1}$ \\
\hline BRAZIL & 438 & 455 & 473 \\
\hline
\end{tabular}

Source: Brasil (2014).

If the results obtained in the large-scale (national) evaluations are used to classify and create competition among institutions with the understanding that such classification and competition would improve educational quality, it is assumed, according to Souza and Oliveira (2003, p. 890), that,

[...] accepting inequality as a condition of producing quality, since the conditions of the school systems and units are different and diverse, would be moving in the direction of intensifying the processes of segregation and social and educational selection.

Chirinéa and Brandão's in 2010 compared two schools, one with an IDEB of 8.2 and the other with an IDEB of 2.4. They found that some factors, such as management type, organizational climate, teachers' sense of belonging, students' socioeconomic status, and students' cultural status, are crucial to educational quality and are not considered in the evaluation results (CHIRINÉA; BRANDÃO, 2015, p. 474). To the extent that the state, through its educational policies, began to use large-scale evaluations as a control mechanism, the concept of quality was solely indicated by the students' test results. Although it is not possible to accurately measure quality with this one method, there are numerous mechanisms to achieve the proposed goals. Freitas (2007) warns that, due to the IDEB's pressures on them, schools may try to beat the system (get around the rules, regulations, or other means of control to achieve a goal) by teaching students how to take the tests or inducing students with academic difficulties to be absent on test day.

This problem leads to the ideas presented by Ball (2010) regarding performativity; penetrating into teachers' daily practices, it seeks to contribute to constructing a convincing institutional performance, but influences teachers' subjectivity. 
The indices are published, generating clear competition among schools in the same region, reaching an extreme in which some schools become linked to a differentiated functional gratification, depending on the extents of classification and levels of achievement on the evaluations.

Thus, given the "current tendency to focus educational questions almost exclusively on measuring and comparing educational results, there is a need to return to the discussion on the aims and purposes of education" (AFONSO, 2009b, p. 25). When test results are published as the only way to measure quality, without examining other factors that relate to whether a school is of high quality or not, it is not clear how the school community and society understand the objective and the subjects of education.

\section{Evaluation and quality of basic education via emancipation}

The conception of emancipation was being constructed historically and has its origins in the eighteenth century (1668-1744), with the Italian philosopher Giambattista Vico, who dedicated himself to the study of subjects of philosophy, history, law, among which the emancipation. Emancipation assumes that the human being is the subject "artificer of his own act" and he escapes in all aspects of his life (CIAVATTA, 2014, p. 86). However, according Ciavatta (2014, p. 83) emancipation cannot be summed up to a concept, since it is made up of the "human praxis, is the history of individuals, groups and social classes that their achievement elements can be understood". We find the discussion of the concept of emancipation in important philosophical bases such as Kant, Marx, Adorno, Horkheimer and Habermas, each author bringing different interpretations to this concept.

To aim the expectations of democracy which "demands emancipated people" (ADORNO, 1995) it is necessary "unbalance knowledge in favor of emancipation", based on two strategies: the revaluation of chaos (which implies the value and dialogue with knowledge of minorities) and the revaluation of solidarity (which implies reciprocity through the construction and recognition of inter-subjectivity). "The emphasis on solidarity converts the community in a privileged field of emancipatory knowledge" (SANTOS, 2009, p. 81).

In this line of reasoning, knowledge has public and social value. It belongs to the sphere of human rights and civilizational projects. Knowledge is an integral content of human, ethical, political, moral 
and aesthetic formation. It must not be, or should not be, simple gear of profits optimization (DIAS SOBRINHO, 2015, p. 585).

Therefore, in the analysis of policies and the execution of emancipatory educational practices it is important to understand the different dimensions which permeate the knowledge emancipation, guided by the awareness of subjects of historical, geographically and culturally rights situated and circumstantial.

Recent educational policies suggest movement toward a curriculum that recognizes previously marginalized groups to ensure and promote human rights. One such policy is Resolution 04/2010, which establishes the General National Curriculum Guidelines for Basic Education; the other is Resolution No. 1 of May 30, 2012, which establishes the National Guidelines for Human Rights Education. Resolution 01/2010 defines the General National Curriculum Guidelines for the stages and modalities of Basic Education, "based on every person's right to their full development, to preparation to exercise citizenship and to qualification for work, living and coexisting in an educational environment" (BRASIL, 2010). Article 2 $\$ 2$ of Resolution 01/2012 deems that, "educational systems and their institutions are responsible for providing Human Rights Education, implying the systematic adoption of these guidelines for all those involved in educational processes" (BRASIL, 2012). Thus, some advances are visible in the new policies, but these advances are still more in the realm of discourse than practice.

It is therefore necessary to reiterate the challenge posed to building curricula and evaluation processes that define quality in the emancipatory sense that can respect the subjects of educational processes and their similarities and differences with education that develops "in spaces marked by mutual understanding, respect and responsibility" (BRASIL, 2007, p. 32). In contrast to Decree No. 6094/2007, which intensifies regulation. Resolutions 04/2010 and 01/2010 advance from the perspective of emancipatory education, but are limited by their emphases on evaluation results and the physical characteristics and conditions of schools.

This social, economic, and political status quo is thus maintained despite policies seeking education that is equitable and promotes guaranteed rights. Along those lines, we highlight the guidelines of Resolution No. 04/2010, in which the concept of quality that is defended is the social quality of education. In Article 9, we read that education, "adopts the student and learning as being central," requiring compliance with nine requirements, including "reviewing conceptual references" in relation to numerous educational spaces and times; consideration for "inclusion, 
valuing differences and attending to plurality and cultural diversity"; and focusing on "a love of learning and the evaluation of learning" (BRASIL, 2010).

Furthermore, it should be noted that Resolution No. 04/2010 reaffirms LDB No. 9394/96's position that the subjects of education are individuals who have equal rights (in terms of access to and permanence in school), have the freedom to learn/teach, and are educated based on the principle of respect for freedom and rights, although it excludes the "appreciation for tolerance" found in the LDB. The evolution of educational policies, particularly curriculum policies, regarding the issue of identity/diversity, thereby begins to emerge.

In fact, an "appreciation for tolerance," as Saramago (2003) clearly explains, is of little value when we consider the extent of diversity and inequality present in contemporary Brazilian society,

I am against tolerance because it is not enough. Tolerating the existence of the other and allowing them to be different is still worth very little. When you are tolerant, it is something you are conferring, and this is not an equal relationship, but the superiority of one over the other. We have already reflected on intolerance. Intolerance is bad, but tolerance is not as good as it sounds. We should create a relationship between people that excludes tolerance and intolerance.

Despite these shortcomings, the subject of education is conceived of as a subject with a plurality of ideas and with a life outside of the school context to be valued and understood in its connections to work and social practices. Unlike the LDB, this document does not reduce diversity to racial/ethnic difference or even to the biological diversity related to the processes of including people with specific educational needs. Thus, the anthropological perspective, with its focus on the subject, as expressed in the Resolution, recognizes and valorizes diversity as the differences and specificities of individuals, as expressed in Article 20:

Respect for learners and their mental, socio-emotional, cultural and identitarian times is a guiding principle of all educational activities. It is the responsibility of systems to create conditions for children, adolescents, youths and adults, with all their diversity, to have the opportunity to receive the formation that corresponds to their age in the school journey (BRASIL, 2010). 
The recognition and valorization of diversity, or diversities, are mentioned throughout parts of the Resolution as a requirement for social quality regarding the organization of basic education in the specifications of different stages and modalities of education and in relation to the political-pedagogical project. In terms of the last item of that list, diversity should be an integral component of the political-pedagogical project, as expressed in paragraph 3 of Article 43:

The mission of the school unit, the socio-educational, artistic, cultural and environmental roles, the gender, ethnicity and cultural diversity issues that make up the educational activities, and the curriculum organization and management are integral components of the political-pedagogical project, [...] (BRASIL, 2010).

The dignity of individuals and citizens is cited in Article 3 as based on the Constitution because these principles assume, "equality, freedom, plurality, diversity, respect, social justice, solidarity and sustainability" (BRASIL, 2010), all of which are linked to the anthropological view expressed in the document. The emancipatory perspective, in the view of the objectives of education and evaluation, are more evident in Resolution No. 04/2010 than in previous documents. The meaning of "Basic Education" is understood to be a right by which other rights can be guaranteed, as expressed in Article 5:

Basic Education is a universal right and indispensable foundation for the exercise of full citizenship, on which the possibility to gain all other rights depends, defined in the Federal Constitution, in the Children and Adolescents Statute (Estatuto da Criança e do Adolescente - ECA), in the regular legislation and in the other provisions enshrining the citizen's prerogatives (BRASIL, 2010).

The numerous levels at which the evaluation processes comprising the evaluation system are developed are specified in Article 46 on learning evaluation and institutional evaluation, and they are specified in the following articles. There is also an indication that the evaluation system is a constitutive element of the operationalization of the Guidelines (Article 42) and that, "actions for systematically monitoring the results of the internal and external evaluation process [...], including data referring to the IDEB" must be considered in schools' political-pedagogical projects (BRASIL, 2010).

According to Resolution No. 04/2010, the objectives of evaluation would be to: (1) question the educational act itself to transform it into a political act (learning 
evaluation); (2) review the goals and targets (internal and external institutional evaluation) while accounting for a school's mission, the social quality of learning, and the targeted school; (3) signal to society when a school offers a quality education, as defined; and (4) consider the goals and targets developed collectively at a school (school network evaluation). Thus, Resolution 04/2010 broadens and reframes the anthropological and teleological views set out in the LDB by giving greater emphasis to Santos (2009) notion of "knowledge-emancipation."

With the same bias as Resolution 04/2010, Resolution No. 01/2012 establishes the National Guidelines for Human Rights Education. In Article 2, Human Rights Education is described as:

one of the cornerstones of the right to education, it refers to the use of educational conceptions and practices based on human rights and its promotion, protection, defense and application in the daily and civic life of subjects with rights and individual and collective responsibilities (BRASIL, 2012, emphasis added).

The anthropological and teleological aspects of Resolution No. 01/2012 include the notion that the subject is a "subject with rights" who should be guaranteed the right to social change and transformation. These aspects of the subject would be based on the development of Human Rights Education guided by seven principles: "I: human dignity; II: equal rights; III: recognition and valorization of differences and diversities; IV: a secular state; V: democracy in education; VI: transversality, experience and comprehensiveness; and VII: socio-environmental sustainability" (BRASIL, 2012). In this document, there is an indication that human rights education is considered in planning and evaluation processes. Article 6 of Resolution No. 01/2012 states that:

Human Rights Education, in a transversal manner, should be considered in the construction of Political-Pedagogical Projects (PPP); School Regulations; Institutional Development Plans (Planos de Desenvolvimento Institucionais - PDI); Pedagogical Programs (Programas Pedagógicos de Curso - PPC) at Higher Education Institutions; didactic and pedagogical materials; the teaching, research and extension model; and management, as well as different evaluation processes (BRASIL, 2012, emphasis added).

Thus, although the concept of evaluation is not explicit, there is an indication that Human Rights Education should be considered within the evaluation processes and 
at specific educational levels, taking as a reference the principles and assumptions that are inherent to it.

Although the emancipatory bias predominates, Resolution No. 1/2012 can be an instrument of regulation, depending on how it might be contextualized and applied. A Human Rights Education that emphasizes duties over rights, utilizes moral values over ethics, values one culture over others, and that, therefore, disregards cultural diversity, may develop knowledge-regulation; however, it will never develop knowledge-emancipation. On the other hand, Resolution Nos. 4/2010 and $1 / 2012$ both enable the construction of an emancipatory educational project, comprising "a project for learning conflicting knowledge with the aim of using it to produce radical and destabilizing images of the social conflicts that took place in the past, images capable of fomenting outrage and rebellion. Education, therefore, for nonconformity" (SANTOS, 1996, p. 17).

It is thus expected that evaluative processes respect the dignity, diversity, and rights of individuals as a way to promote human development. Since "educational quality, in the emancipatory perspective, goes beyond efficient and economic criteria. (EYNG, 2015, p.143). According to Afonso (2009b, p. 25), the construction of democratic and transparent evaluation models implies that, "the social, cultural and political valorization of the processes of participation, negotiation and justification, and the adoption of explicit models of justice and equity (social, educational and evaluative)". To this end, an evaluation that punishes, threatens, and/or humiliates through hierarchical categorization must be repudiated and banned from school practices.

The reflection on the contradiction and tension between regulation / emancipation and its contradictions in the contemporary context is a challenge because "[...] to dare to think emancipation in times of broad and radical change of insecurity and instability, of new emergency plurality [...] is to put yourself in the eye of the storm" (CARVALHO, 2008, p. 3). Since this emancipation, "[...] it is an open, highly plural process, materializing in " 'emancipatory experiences' that spread through different parts of the world, with different designs and formats that well embody the difference" (CARVALHO, 2008, p. 7). In this sense, promoting emancipatory experiences presupposes the guarantee of rights, the recognition of differences and overcoming the regulation that standardizes the subject.

We emphasize that "the guarantee of the right, as emancipatory possibility, requires a counter-hegemonic policy, considering the effectiveness of social quality for all” (EYNG, 2015, p. 143). 


\section{Final considerations}

The question posed at the beginning of this essay concerned the ways that a contradiction present in basic educational policies in terms of proposals for emancipating and regulating the subjects affects policy. It is observed that evaluation that has been conducted in a way that is based only on the results of indices is moving away from its original intent to an objective measure of educational achievement. Moreover, if we consider the consequences of valorization for the daily lives of teachers, we see a valorization of performativity, as described by Ball (2010), which strongly influences the subjectivity of all who work in basic education and, most of all, the students. Thus, it is necessary and urgent to change to the perspective that has been adopted for what is referred to as basic education's quality.

A guarantee of equal rights, when associated with the recognition and appreciation of differences and diversities, enables socio-cultural identities to be strengthened and previously marginalized groups to find a voice and a space which promotes intercultural dialogue and respect for the subjects of educational processes in their similarities and differences, which occurs through an education that develops "in spaces marked by mutual understanding, respect and dialogue. These are challenges of Human Rights Education, which consider and respect cultural diversity among students and development of knowledge-emancipation.

The aim is to promote the balanced dynamic proposed by Santos $(2009$, p. 78$)$ that superimposes emancipation onto regulation. In other words, a school's emphasis should be on diversity and the guarantee and promotion of rights, with the understanding that the valorization and recognition of diversity is an opportunity to improve the quality of education, including the improvement of test indices while maintaining quality. Doing so would intensify the construction of legitimate identities.

When considering the test results achieved by schools, it is crucial to understand those results in the contexts in which they occur because teacher and student performances depend on contextual factors.

Thus, what is sought as educational objectives and, therefore, as evidence of social quality is the experience of Human Rights Education, a dialogue within and among differences, acknowledgement of diversities, rigorous ethics regarding approval or rejection, and, particularly, cooperation and solidarity among the subjects of and/or in education. These objectives are the anthropological and 
teleological foundations of an emancipatory education that allows for the creation of resistance and project identities.

This vision is a sizable challenge that embraces the processes that can bring more inclusion and social emancipation of subjects of rights, citizenship and solidarity on a global and local level. 


\section{Políticas de avaliação e de educação em direitos humanos: as contradições entre regulação $e$ emancipação na educação básica}

\section{Resumo}

A investigação tem por objetivo analisar as contradições entre aspectos antropológicos e teleológicos nas políticas de avaliação e de educação em direitos humanos para a educação básica. O estudo assume como categoria central a contradição na análise de documentos legais relativos às temáticas em discussão. Os resultados da pesquisa apontam o quanto as contradições nas perspectivas antropológicas e teleológicas, dessas políticas incidem como obstáculos na efetivação da educação básica de qualidade social. As políticas de avaliação da educação básica têm como finalidade a regulação, com vistas à produção de índices que normatizam e hegemonizam os sujeitos, produzindo identidades legitimadoras. Por outro lado, as políticas de educação em direitos humanos têm por finalidade a emancipação dos sujeitos, considerados na diversidade que os caracteriza e configura, possibilitando a constituição de identidades de resistência e de projetos capazes de atuar numa perspectiva contra-hegemônica.

Palavras-chave: Políticas públicas. Avaliação. Direitos humanos.

\section{Políticas de evaluación y educación en derechos humanos: las contradicciones entre regulación y emancipación en la educación básica}

\section{Resumen}

La investigación tiene como objetivo analizar las contradicciones entre los aspectos antropológicos y teológicos de la evaluación y los derechos humanos en las políticas educativas para la educación básica en Brasil. El estudio toma como categoría central la contradicción en el análisis de documentos legales relacionados con los temas en discusión. Los resultados de la investigación muestran cómo las contradicciones en las perspectivas antropológica y teológica, asumidas por estas políticas obstruyen la ejecución de una educación básica de calidad social. Las politicas de evaluación en Brasil están dirigidas a la regulación, con miras a los índices que normalizan y homogeneizan los sujetos de la educación, produciendo identidades legitimadoras. Por otra parte, las políticas educativas en los derechos humanos tienen como objetivo la emancipación de los sujetos, considerando la diversidad que los caracteriza y configura, lo que permite la creación de identidades de resistencia y de proyectos identidades que pueden operar desde una perspectiva contra hegemónica.

Palabras clave: Políticas públicas. Evaluación. Derechos humanos. 


\section{References}

ADORNO, T. W. Educação e emancipação. São Paulo: Paz e Terra, 1995.

AFONSO, A. J. Estado, políticas educacionais e obsessão avaliativa. Contrapontos, Itajaí, v. 7, n. 1, p. 11-22, jan./abr. 2007.

. Avaliação educacional: regulação e emancipação: para uma sociologia das políticas avaliativas contemporâneas. 4. ed. São Paulo: Cortez, 2009a.

. Nem tudo o que conta em educação é mensurável ou comparável: crítica à accountability baseada em testes estandardizados e rankings escolares. Revista Lusófona de Educação, Lisboa, v. 13, n. 13, p. 13-29, 2009 b.

BALL, S. J. Diretrizes políticas globais e relações políticas locais em educação. Currículo sem Fronteiras, Rio de Janeiro, v. 1, n. 2, p. 99-116, jul./dez. 2001.

. Educação global S.A.: novas redes políticas e o imaginário neoliberal. Ponta Grossa: Editora UEPG, 2014.

. Novos estados, nova governança e nova política educacional. In:

APPLE, M. W.; BALL, S. J.; GANDIN, L. A. (Org.). Sociologia da educação: análise internacional. Porto Alegre: Penso, 2013. p. 177-89.

. Performatividades e fabricações na economia educacional: rumo a uma sociedade performativa. Educação \& Realidade, Porto Alegre, v. 2, n. 35, p. 37-55, maio/ago. 2010.

BARDIN, L. Análise de conteúdo. Lisboa: Edições 70, 1995.

BRASIL. Comitê Nacional de Educação em Direitos Humanos. Plano Nacional de Educação em Direitos Humanos - PNEDH. Brasília, DF: Secretaria Especial dos Direitos Humanos, Ministério da Educação, 2007a.

. Constituição. Constituição da Republica Federativa do Brasil. Brasília, DF: Senado, 1988.

. Decreto $n^{\circ} 6.094$, de 24 de abril de 2007. Dispõe sobre a implementação do Plano de Metas Compromisso Todos pela Educação, pela União Federal, em regime de colaboração com Municípios, Distrito Federal e Estados, e a participação das famílias e da comunidade, mediante programas e ações de assistência técnica e financeira, visando a mobilização social pela melhoria da qualidade da educação básica. Diário Oficial da União, Brasília, DF, 25 abr. $2007 \mathrm{~b}$. 
BRASIL. Lei n ${ }^{\circ} 9.394$, de 20 de dezembro de 1996. Estabelece as diretrizes e bases da educação nacional. Diário Oficial da União, Brasília, DF, 23 dez. 1996.

. Lei $\mathrm{n}^{\mathrm{o}} 13.005$, de 25 de junho de 2014. Aprova o Plano Nacional de Educação - PNE e dá outras providências. Diário Oficial da União, Brasília, DF, 26 jun. 2014, Edição Extra, p. 1-7.

. Ministério da Educação. Conselho Nacional de Educação. Resolução CNE/CEB n ${ }^{\circ}$ 04, de 13 de julho de 2010. Define Diretrizes Curriculares Nacionais Gerais para a Educação Básica. Diário Oficial da União, Brasília, DF, 14 jul. 2010, p. 824.

. Ministério da Educação. Conselho Nacional de Educação. Resolução CNE/CP n ${ }^{\circ}$ 1, de 30 de maio de 2012. Estabelece Diretrizes Nacionais para a Educação em Direitos Humanos. Diário Oficial da União, Brasília, DF, 31 maio 2012, p. 48.

CARVALHO, A. M. P. D. Experiências emancipatórias em tempos de crise e transição: potencialidades da utopia democrática. In: CONGRESSO PORTUGUÊS DE SOCIOLOGIA MUNDOS SOCIAIS: SABERES E PRÁTICAS, 6., 2008, Lisboa. Anais... Lisboa, 2008. p. 1-13.

CASTELLS, M. O poder da Identidade. 6. ed. São Paulo: Paz e Terra; 2008.

CELLARD, A. A análise documental. In: POUPART, J. et al. (Orgs.). A pesquisa qualitativa: enfoques epistemológicos e metodológicos. 2. ed. Petrópolis: Vozes, 2010. p. 295-316.

CHIRINÉA, A. M.; BRANDÃO, C. F. O IDEB como política de regulação e legitimação da qualidade: em busca de significados. Ensaio: Avaliação e Políticas Públicas em Educação, Rio de Janeiro, v. 23, n. 87, p. 461-84, abr./jun. 2015. doi:10.1590/S0104-40362015000100019

CIAVATTA, M. Emancipação: a historicidade do conceito e a polêmica no processo real da existência humana. Trabalho Necessário, Rio de Janeiro, v. 12, n. 18, jan./jun. 2014. Disponível em: <http://www.uff.br/ trabalhonecessario/images/TN18_-_artigo_do_dossie_-_Maria_Ciavatta.pdf $>$. Acesso em: 17 mar. 2016.

DIAS SOBRINHO, J. Avaliação como Instrumento da formação cidadã e do desenvolvimento da sociedade democrática: por uma ético-epistemologia da avaliação. In: RISTOFF, D.; ALMEIDA JUNIOR, V. P. Avaliação 
participativa: perspectivas e desafios. Brasília, DF: Instituto Nacional de Estudos e Pesquisas Educacionais Anísio Teixeira, 2005. p. 15-38.

. Avaliação educativa: produção de sentidos com valor de formação. Avaliação (Campinas), v. 13, n. 1, p. 193-207, 2008. doi:10.1590/S1414-40772008000100011

. Campo e caminhos da avaliação: a avaliação da educação superior no Brasil. In: FREITAS, L. C. (Org.). Avaliação: construindo o campo e a critica. Florianópolis: Insular, 2002. p. 13-62.

. Universidade fraturada: reflexões sobre conhecimento e responsabilidade social. Avaliação (Campinas), v. 20, n. 3, p. 581-601, mar. 2015. doi:10.1590/S1414-40772015000300002

DUARTE, C. S. Direito público subjetivo e políticas educacionais. São Paulo Perspectiva, São Paulo, v. 18, n. 2, p. 113-8, abr.jun. 2004. doi:10.1590/S0102-88392004000200012

EYNG, A. M. Currículo e avaliação: duas faces da mesma moeda na garantia do direito à educação de qualidade social. Revista Diálogo Educacional, Curitiba, v. 15, n. 44, p. 133-55, jan./abr. 2015. doi:10.7213/dialogo.educ.15.044.DS06

FERNANDES, C. O.; FREITAS, L. C. Indagações sobre currículo: currículo e avaliação. Brasília, DF: Ministério da Educação, 2007.

FREITAS, L. C. Eliminação adiada: o caso das classes populares no interior da escola e a ocultação da (má) qualidade do ensino. Educação e Sociedade, Campinas, v. 28, n. 100, p. 965-87, out. 2007. doi:10.1590/S0101-73302007000300016

HOFFMANN, J. Avaliar para promover: as setas do caminho. Porto Alegre: Mediação, 2001.

ORGANISATION FOR ECONOMIC CO-OPERATION AND DEVELOPMENT - OECD. Programme for International Student Assessment (PISA). 2016.

Disponível em: $<$ http://www.oecd.org/pisa/aboutpisa/> Acesso em: 16 mar. 2016.

SANTOS, B. S. A crítica da razão indolente: contra o desperdício da experiência. 7. ed. São Paulo: Cortez, 2009.

Paulo: Cortez, 2010.

. A gramática do tempo: para uma nova cultura política. 3. ed. São 
SANTOS, B. S. A universidade no século XXI: para uma reforma democrática e emancipatória da universidade. In: APPLE, M. W.; BALL, S. J.; GANDIN, L. A. (Org.). Sociologia da educação: análise internacional. Porto Alegre: Penso, 2013. p. 301-11.

. Introdução a uma ciência pós moderna. Rio de Janeiro: Graal, 1989.

. Para uma pedagogia do conflito. In: SILVA, L. H.; AZEVEDO, J. C.; SANTOS, E. S. (Orgs). Novos mapas culturais, novas perspectivas educacionais. Porto Alegre: Sulina, 1996. p. 15-33.

. Pela mão de Alice: o social e a política na pós modernidade. 12. ed. São Paulo: Cortez; 2008.

. Por uma concepção multicultural de direitos humanos. Lua Nova Revista de Cultura e Política, n. 39, p. 105-24, 1997.

SANTOS, B. S.; MENESES, M. P. (Org.). Epistemologias do Sul. São Paulo: Cortez, 2010.

SARAMAGO, J. Tolerância não é igualdade. $O$ Globo, 2003. Disponível em: http://www.citador.pt/textos/tolerancia-nao-e-igualdade-jose-de-sousa-saramago. Acesso em 26 dez. 2014.

SAUL, A. M. Avaliação emancipatória: desafios à teoria e à pratica de avaliação e reformulação de currículo. 4. ed. São Paulo: Cortez, 1999.

SAVIANI, D. Vicissitudes e perspectivas do direito à educação no Brasil: abordagem histórica e situação atual. Educação e Sociedade, Campinas, v. 34, n. 124, p. 743-60, set. 2013. doi:10.1590/S0101-73302013000300006

SOARES, J. F.; XAVIER, F. P. Pressupostos educacionais e estatísticos do IDEB. Educação e Sociedade, v. 34, n. 124, p. 903-23, jul./set. 2013. doi:10.1590/S0101-73302013000300013

SOUZA, S. Z. L.; OLIVEIRA, R. P. Políticas de avaliação da educação e quase mercado no Brasil. Educação e Sociedade, Campinas, v. 24, n. 84 p. 873-95, set. 2003. doi:10.1590/S0101-73302003000300007

TORRES SANTOMÉ, J. T. Currículo escolar e justiça social: o cavalo de Tróia da educação. Porto Alegre: Penso, 2013. 


\section{Informações dos autores}

Ana Maria Eyng: Doutorado em Pedagogia, Universidade Autônoma de Barcelona-UAB, Barcelona, Espanha. Professora Titular PUCPR. Contato: eyng.anamaria@gmail.com

Thais Pacievtch: Doutorado em Educação e Professora da PUCPR. Pedagoga no Instituto Federal de Educação, Ciência e Tecnologia - IFPR do Paraná. Contato: thaispacievitch@gmail.com

Maria de Lourdes do Prado K. D’Almeida: Doutoranda em educação, PUCPR.Prefeitura Municipal de Curitiba - Secretaria Municipal de Educação de Curitiba PR - Departamento de Ensino Fundamental. Contato: mariprado@sme.curitiba.pr.gov.br

Maria de Lourdes Gisi: Bolsista Produtividade da Fundação Araucária/PR. Pós-Doutorado, Universidade de Genebra, Suíça. Professora Titular da PUCPR. Contato: gisi. marialourdes@gmail.com 